\title{
PELATIHAN TEKNIK ASERTIF UNTUK MENGURANGI KECEMASAN KOMUNIKASI INTERPERSONAL PADA SISWA KELAS X SMA NEGERI 12 BANJARMASIN
}

\author{
Ririanti Rachmayanie dan Sulistiyana
}

FKIP, Bimbingan dan Konseling, Universitas Lambung Mangkurat E-mail : ririanti.bk@ulm.ac.id

\begin{abstract}
ABSTRAK
Pelatihan teknik asertif ini bertujuan untuk mengurangi kecemasan siswa kelas $\mathrm{X}$ dalam berkomunikasi interpersonal di SMA Negeri 12 Banjarmasin dengan menggunakan pendekatan konseling individual. Setelah itu dilakukan pembagian angket terhadap 30 orang siswa kelas $\mathrm{X}$ berdasarkan hasil observasi tak berstruktur maka didapat data 1 orang siswa memiliki kategori yang sangat tinggi sehingga perlu diberikan pendekatan konseling individual. Pelaksanaan pelatihan dilakukan selama 4 kali pertemuan. Hasil menunjukkan bahwa siswa telah berhasil mengurangi kecemasan sosial, berdasarkan hasil pengamatan tak berstruktur yang dilakukan oleh guru BK di SMA Negeri 12 Banjarmasin.
\end{abstract}

Kata Kunci : Kecemasan Komunikasi Interpersonal, Pelatihan Teknik Asertif, Pendekatan Konseling Individual

\section{PENDAHULUAN}

Manusia diharuskan untuk
mampu berinteraksi dan
berkomunikasi dengan orang lain di
lingkungannya untuk kebutuhan dan
kelangsungan hidupnya karena
manusia diciptakan tidak sendiri, dan
tidak ada manusia yang bisa hidup
sendiri. Untuk membentuk interaksi
perlu adanya komunikasi yang baik
antar manusia, karena apabila individu
tidak dapat berkomunikasi dengan baik
maka tidak akan terbentuk interaksi
yang baik pula.

$$
\text { Kenyataanya di lingkungan }
$$
terlihat tidak semua individu dapat berkomunikasi secara lancar dengan orang lain. Komunikasi tidak lancar banyak terjadi di sekolah. Masih ada siswa mengalami kesulitan dalam berkomunikasi dengan orang lain (komunikasi interpersonal), seperti teman di kelas dan juga guru, dan baik dalam proses belajar di kelas maupun dalam suasana informal di luar kelas (Siska, dkk. 2003:68).

Sekolah merupakan lingkungan sosial dimana siswa harus menyesuaikan dirinya dengan lingkungan sekolahnya, sehingga siswa dapat belajar untuk memahami kewajibannya sebagai pelajar, serta 
mampu berkomunikasi dengan baik.

Komunikasi sangat penting untuk menunjang siswa dalam pembelajarannya di sekolah, apabila siswa memiliki komunikasi yang kurang lancar akan mempersulit siswa tersebut memperoleh informasiinformasi yang seharusnya ia dapatkan. Namun demikian, banyak permasalahan yang timbul berkaitan dengan komunikasi. Dalam proses komunikasi ada salah satu masalah yang dihadapi dalam berkomunikasi yang dikenal dengan istilah hambatan komunikasi

(communication apprehension).

Senada dengan ungkapan Burgoon \& Ruffner (1978) dalam buku "Human Communication" menjelaskan bahwa communication apprehension merupakan istilah yang tepat untuk menggambarkan reaksi negatif dalam bentuk kecemasan yang dialami seseorang dalam pengalaman komunikasinya, baik itu kecemasan berbicara di muka umum maupun kecemasan komunikasi interpersonal (Fathunnisa, 2012:136).

Hambatan komunikasi bisa terjadi karena ada kecemasan yang dialami dalam pengalaman komunikasinya baik di lingkungan rumah, luar rumah maupun disekolah. Komunikasi interpersonal yang baik sangat diperlukan oleh semua orang, terutama ketika seseorang melakukan akivitas di luar rumah, seperti sekolah. Akibat dari kecemasan tersebut akan mengganggu komunikasi interpersonalnya.

Kecemasan adalah salah satu gangguan emosi yang bisa dirasakan karena gejala fisiologisnya sangat jelas, jantung berdetak cepat, perut terasa diremas-remas, gemetar pusing dan berbagai gejala fisiologis lainnya yang disebabkan oleh kecemasan. Kecemasan disebabkan karena seseorang mempercayai bahwa keadaan lebih menakutkan, daripada kenyataan yang sebenarnya. Gejalagejala fisik dari kecemasan memainkan peranan yang sangat penting dalam proses melebih-lebihkan ancaman yang dihadapi, ancaman-ancaman tersebut dilihat sebagai tanda-tanda terpercaya dari terjadinya sesuatu yang sangat buruk (Wilding, Milne, 2013:235).

Jadi, dapat disimpulkan bahwa kecemasan komunikasi interpersonal adalah bentuk reaksi negatif dari individu berupa kecemasan yang dialami seseorang ketika berkomunikasi dengan individu lain 
dalam berbagai situasi umum, individu ataupun kelompok karena adanya rasa khawatir tentang respon atau penilaian orang lain terhadap dirinya.

McCroskey (dalam Febiyanti, 2007:3) Individu yang mengalami kecemasan komunikasi interpersonal ini akan menjadi takut, gugup, tegang, kaku, serta kehilangan topik pembicaraan dalam menjalin percakapan antar pribadi, situasi lingkungan baru, seseorang yang baru dikenal dan kecemasan komunikasi terhadap individu yang mempunyai tingkatan status lebih tinggi.

Pada kondisi tersebut individu cenderung menghindari situasi komunikasi yang ragu, takut salah, serta tidak punya keberanian untuk menyampaikan informasi yang ingin dikemukakan. Reaksi hambatan komunikasi tersebut dilihat manifestasinya melalui reaksi negatif atas kecemasan berkomunikasi pada percakapan umum, rapat, kelompok kecil dalam diskusi, maupun interaksi face to face.

Dari hasil wawancara tak berstruktur dengan guru BK di SMA Negeri 12 Banjarmasin maka ditemukan adanya permasalahan kecemasan dalam berkomunikasi interpersonal pada siswa kelas $\mathrm{X}$ yang paling banyak terjadi dengan ciri suka menyendiri dan cenderung menghindar bila diajak bicara oleh teman sekelas maupun guru dan baik dalam proses pembelajaran di kelas maupun dalam suasana informal di luar kelas, ketika berbicara dengan orang lain merasa gugup, dan terbata-bata, tidak berani mengungkapkan pendapatnya ketika sedang kerja kelompok ataupun dalam bentuk komunikasi lainnya.

Untuk mengurangi kecemasan komunikasi interpersonal siswa maka pelaksana $\mathrm{PkM}$ mengusulkan untuk dilaksanakan pendekatan konseling individual menggunakan konseling behavior dalam bentuk pelatihan asertif.

Apabila didefinisikan maka pelatihan asertif adalah prosedur pengubahan perilaku yang mengajarkan, membimbing, melatih, dan mendorong klien untuk menyatakan dan berperilaku tegas dalam situasi tertentu. Konseli diajarkan untuk menguasai perilakunya dalam menghadapi perilaku yang problematik untuk meningkatkan efektivitas kehidupan dan mencegah kecemasan (Purwanta, 2015:165).

Telah dibuktikan bahwa pelatihan 
asertif yang dilakukan oleh Rizki, Kurnia dkk (2015) dengan judul "Pelatihan Asertivitas terhadap Penurunan Kecemasan Sosial pada Siswa Korban Bullying”, menunjukkan terdapat perbedaan tingkat kecemasan sosial siswa korban bullying yang sangat signifikan antara sebelum dan sesudah diberikannya pelatihan asertivitas.

Temuan dari Cucu Arumsari (2016) "Konseling Individual Dengan Teknik Modeling Simbolis Terhadap Peningkatan Kemampuan Kontrol Diri”. Kesimpulan dari penelitian ini adalah bahwa konseling individual dengan teknik modeling efektif meningkatkan kemampuan kontrol diri. Konseling individual dapat memfasilitasi konseli melakukan perubahan perilaku, mengkonstruksi pikiran, mengembangkan kemampuan mengatasi situasi kehidupan, membuat keputusan yang bermakna bagi dirinya dan berkomitmen untuk mewujudkan keputusan dengan penuh tanggungjawab dalam kehidupannya.

Melihat permasalahan tersebut pelaksana $\quad P k M \quad$ bermaksud mengadakan pelatihan asertif untuk membantu siswa mengurangi kecemasan komunikasi interpersonal dengan konseling individual menggunakan teknik latihan asertif, dengan pemberian teknik latihan asertif kepada siswa atau konseli yang memiliki kecemasan interpersonal diharapkan siswa mampu mengurangi kecemasan interpersonal, dan mampu berkomunukasi dengan temannya dengan baik dan lebih efektif lagi.

\section{METODE PELAKSANAAN}

Metode pelaksanaan dilakukan adalah dengan mengadakan observasi tak berstruktur penelitian yang digunakan adalah pertama dilakukan pembagian angket terhadap 30 orang siswa kelas $\mathrm{X}$ berdasarkan hasil observasi tak berstruktur maka didapat data 1 orang siswa memiliki kategori yang sangat tinggi sehingga perlu diberikan pendekatan konseling individual.

Selanjutnya dilakukan pelaksanaan pelatihan asertif melalui pendekatan konseling individual.

\section{HASIL DAN PEMBAHASAN}

Apabila diuraikan secara garis besar maka maka metode pelaksanaan PkM yang dimaksud adalah sebagai berikut: 
1. Pra konseling

a. Pengumpulan data terlebih dahulu tentang siswa yang mengalami kecemasan komunikasi interpersonal.

b. Menyiapkan ruangan konseling yang akan dijadikan tempat proses konseling individual.

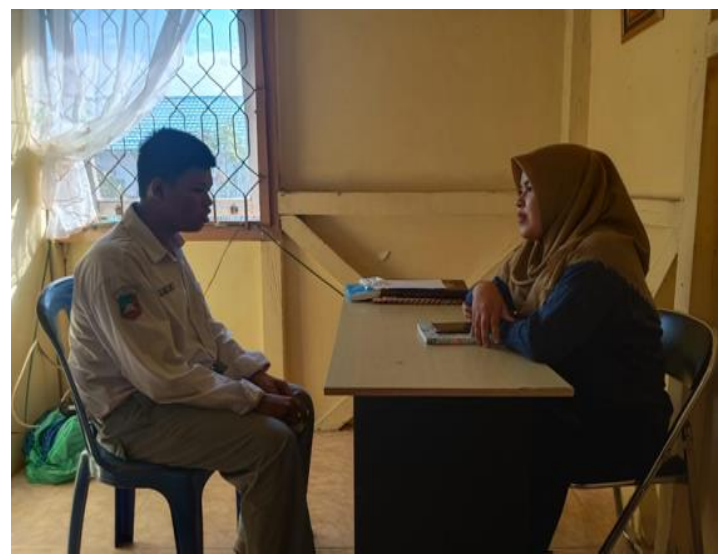

Gambar 1

\section{Pelaksanaan Proses Konseling}

2. Proses konseling

a. Membangun relasi konseling, dalam tahap ini dijelaskan tujuan diadakannya konseling, pelatih memberitahukan kepada konseli bahwa dalam proses konseling ini juga ada asasasas dan kode etik yang dipegang pelatih. pelatih bersama konseli membuat kesepakatan waktu yang disetujui oleh konseli.

b. Melaksanakan tahapan dan menggunakan teknik konseling sesuai teori yang dipilih baik secara tunggal, maupun integratif. Konseli menceritakan permasalahan yang dialaminya kepada pelatih tentang kecemasan komunikasi interpersonal.

1) Langkah 1: Rasional Strategi

a) Pelatih menjelaskan tujuan dari teknik latihan asertif ini untuk mengurangi kecemasan komunikasi interpersonal.

b) Setelah itu pelatih menjelaskan tahapan yang ada dalam teknik latihan asertif.

2) Langkah 2: Identifikasi Keadaan yang Menimbulkan Persoalan

a) Pelatih meminta konseli menceritakan secara terbuka tentang permasalahan yang dihadapi, bahwa kecemasan yang ia alami tidak hanya dengan teman di dalam kelas tapi juga dengan guru-guru. Pada saat kecemasan itu timbul 


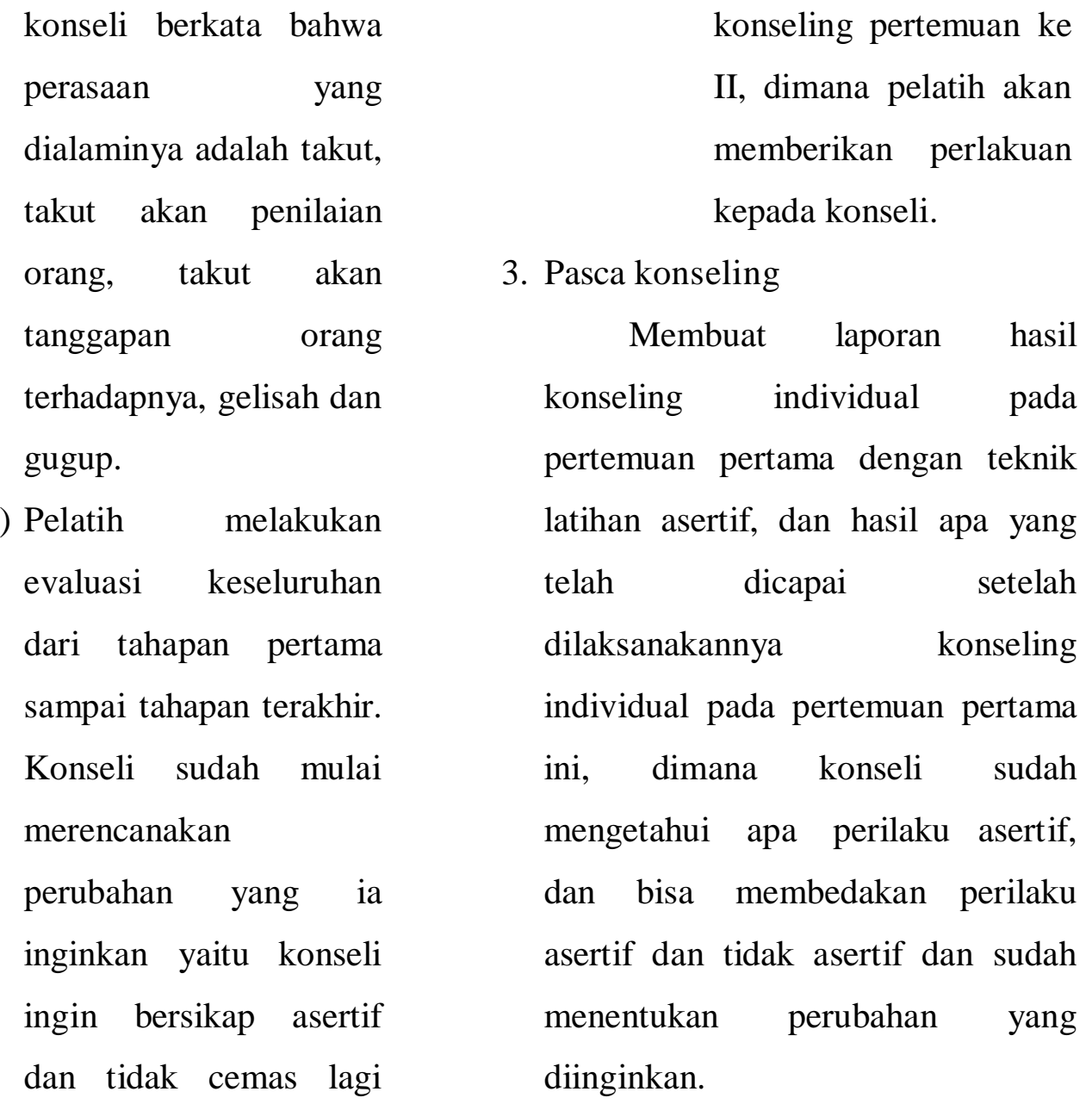

ketika berada di depan umum.

c) Menutup proses konseling. Pelatih memberi tugas rumah pada konseli. Pelatih dan konseli membuat kontrak pelaksanaan konseling dan setelah pertemuan pertama

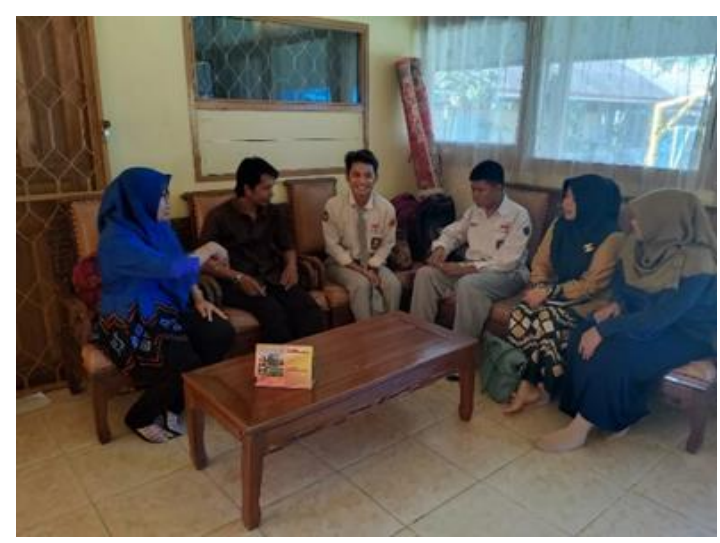

Gambar 2

Penyampaian Hasil Pelatihan Asertif berakhir maka pelatih akan memberitahu konseli bahwa akan dilaksanakan proses

\section{KESIMPULAN}

Pelaksanan layanan konseling individual dengan pelatihan teknik 
asertif mampu mengurangi kecemasan komunikasi interpersonal siswa. Dimana siswa memiliki pemahaman diri tentang kecemasan komunikasi interpersonal yang di alaminya dengan mampu menyebutkan perasaanperasaan cemas yang muncul pada kondisi tertentu. Disamping itu siswa juga memiliki kemampuan dalam membedakan dan memberikan contoh perilaku asertif dan perilaku yang tidak asertif sehingga terjadi perubahan sikap setelah mengikuti pelatihan teknik asertif untuk mengurangi kecemasan komunikasi interpersonal.

\section{DAFTAR PUSTAKA}

Arumsari, Cucu. Konseling individual dengan Teknik Modeling Simbolis terhadap Peningkatan Kemampuan Kontrol Diri. Universitas Muhammadiyah Tasikmalaya. Jurnal Konseling GUSJIGANG, Volume 2: No 1, Tahun 2016.

Darmadi, Hamid. 2014. Metode Penelitian Pendidikan dan Sosial. Bandung: Alfabeta

$\begin{array}{ccc}\text { Fathunnisa, Aghnia. } & \text { Pengaruh } \\ \text { Penyesuaian Diri } & \text { Terhadap } \\ \text { Kecemasan } & \text { Komunikasi }\end{array}$
Interpersonal Pada Remaja di Panti Asuhan Muslimin. Universitas Negeri Jakarta. Jurnal Pelatihan dan Pengukuran Psikologi, Volume 1: No 1, Tahun 2012.

Febiyanti, Fina dan Rahmawati, Mira Aliza. 2007. Hubungan Antara Kepercayaan Diri Dengan Kecemasan Komunikasi Pada Penyalahguna Napza Selama Masa Rehabilitasi. Naskah Publikasi. Yogyakarta: Program Studi Psikologi Fakultas Psikologi Dan Ilmu Sosial Budaya Universitas Islam Indonesia

Purwanta, Adi. 2015. Modifikasi Perilaku: Alternatif Penanganan Anak Berkebutuhan Khusus. Yogyakarta: Pustaka Pelajar.

Rizki, Kurnia, Suakrti, Quratul Uyun. Pelatihan Asertivitas Terhadap Penurunan Kecemasan Sosial Pada Siswa Korban Bullying. Universitas Islam Indonesia. Jurnal, Volume 3: No 2, Tahun 2015 .

Siska, Sudardjo, Esti Hayu Purnamaningsih. Kepercayadan Diri dan Kecemasan Komunikasi Interpersonal Pada Mahasiswa. Universitas Gadjah Mada. Jurnal Psikologi, No 2, Tahun 2003.

Wilding, Christine. \& Milne, Aileen. 2013. Cognitive Behavior Theraphy. Jakarta: PT Indeks. 